axial and coronal image include either an $\mathrm{R}$ (for right) or an L (for left) on the appropriate side of the image.

Author Response: Giovanni Castelnovo, Jean P. Hladky, Dimitri Renard, Nimes, France: The authors thank Dr. Berg for his comments on our article. We confirm that the herniation itself was radiologically present on the left side as stated in the article. Motor deficit was present on the right side, which might indeed be confusing, as Dr. Berg stated. We did not further discuss this issue due to space limitations. Motor deficit contralateral to the side of the herniation was probably related to distortion or traction on the right side of the spinal cord.

Editor's Note: My thanks to my colleague Mike Berg for pointing out a potentially confusing situation. His suggestion to indicate the side of the imaging is entirely reasonable. We will be making an addition to the Information for Authors.

(C) 2014 American Academy of Neurology

1. Castelnovo G, Hladky JP, Renard D. Spontaneous transdural spinal cord herniation. Neurology 2014;82:1290.

\title{
CORRECTION
}

\section{IV thrombolysis and renal function}

In the article "IV thrombolysis and renal function" by H. Gensicke et al. (Neurology" 2013;81:1780-1788), there is an error in the introduction. The third sentence should read: "In 2 studies, impaired kidney function was associated with unfavorable outcome after 3 months $^{9-10}$ and in a third with diminished neurologic improvement after 7 days, ${ }^{11}$ while a fourth study revealed no association between impaired kidney function and unfavorable in-hospital outcome. ${ }^{12}$ " The authors regret the error. 


\title{
Neurology
}

\author{
IV thrombolysis and renal function \\ Neurology 2014;83;1583 \\ DOI 10.1212/WNL.0000000000000972
}

This information is current as of October 20, 2014

Updated Information \& Services

Permissions \& Licensing

Reprints including high resolution figures, can be found at: http://n.neurology.org/content/83/17/1583.full

Information about reproducing this article in parts (figures,tables) or in its entirety can be found online at:

http://www.neurology.org/about/about_the_journal\#permissions

Information about ordering reprints can be found online:

http://n.neurology.org/subscribers/advertise

Neurology ${ }^{\circledR}$ is the official journal of the American Academy of Neurology. Published continuously since 1951, it is now a weekly with 48 issues per year. Copyright (O 2014 American Academy of Neurology. All rights reserved. Print ISSN: 0028-3878. Online ISSN: 1526-632X.

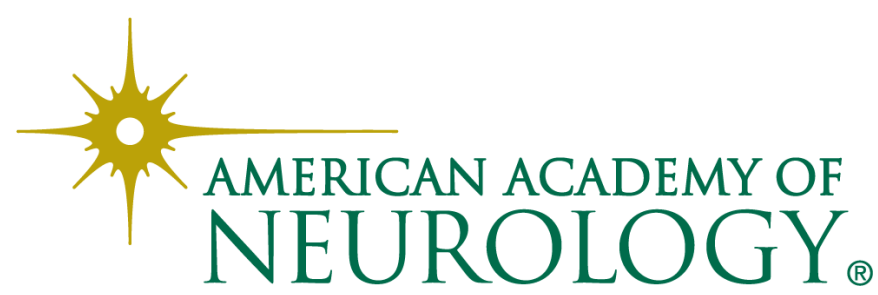

